\title{
Infant Mortality Decline in a Changing Society
}

\author{
KARI PITKÄNEN \\ Research Associate \\ Department of Economic and Social History \\ University of Helsinki
}

\section{Introduction}

When high mortality during the first year of life was observed in Finland after the arrangement of the Swedish-Finnish system of population statistics in the middle of the 18th century, infant mortality remained a continuous concern for almost two centuries. Throughout this time rapid population growth was thought to be of great importance for a country with a relatively small population size. Before the practice of family limitation became common in the beginning of the 20th century, high infant mortality was seen as the main obstacle standing in the way of this pursuit. The number of infant deaths was so prominent that mortality of the other age groups was often not even touched on in the writing of the time. In the middle of the 18th century about one-third of all deaths were children who had died during their first year of life. The proportion decreased slowly but in the late 19th century infant mortality still comprised about one-fourth of all deaths. High infant mortality had so overwhelmed the thoughts of the people at the time that when they calculated how many individuals would survive for "the benefit of the nation», should infant mortality fall to such and such a level, they hardly ever noticed that a considerable part of the children who in such a case would have survived their first year of life would in fact have died before, for example, the age of 15 (see e.g. Ylppö 1921, 352).

The idea that the period between the world wars and especially the $1920 \mathrm{~s}$ forms a crucial period in the development of infant mortality is clearly seen in much scientific and popular writing (see e.g. Tunkelo 1948, 25; A. Ruotsalainen in Toveritar 1925, No. 19; von Bonsdorff 1978, 274). ${ }^{1}$ The train of thought - although not always explicitly expressed - seems to have been that before the 1920 s there prevailed a situation which was characterized by a high level of infant mortality (although perhaps showing some slight indications of decline) caused by insufficient means to affect infant mortality to any significant degree. In the 1920 s a period

' Also in a fairly recent study (Mustonen et al. 1976) concerning the development of infant mortality, the adoption of this view has possibly affected the choice of the year 1910 as the starting point. 
began when infant mortality started to fall rapidly to a level characteristic of an economically and socially developed country. The decline in mortality is attributed to the development of the possibilities to affect mortality through improved medical knowledge and organized systems of maternity and child care. The following quotation is from the memoirs of Arvo Ylppö, a legendary person in Finnish pediatrics, whose significance in the infant mortality decline has been valued very highly (see e.g. Kallio 1973, 274): "When our country thus had gotten a uniform, nationwide system of maternity and child care, one did not have to w?it for long for results. Soon they became visible. - _ - child mortality also began to decline in all age groups, but especially among the infants - - - When it (infant mortality) in our country was still $10-15$ percent in the 1910 s and 1920 s, it had fallen to $5-6$ percent by 1939 (Ylppö 1964, 116).»

This article, however, challenges this stereotypic view concerning the decisive role of the interwar period in the development of infant mortality. Crucial questions to be answered are the following. Does the interwar period or the 1920 s introduce some kind of a different or 'modern' pattern of infant mortality relative to the period prior to the First World War? Did the new means of organized maternity and child care and the progress in medicine have an essential effect on the infant mortality patterns during the interwar period? Through these questions this article attempts to increase our knowledge about the infant mortality decline during the first part of the mortality transition in Finland. This article is based on aggregate data produced by the Finnish population statistics system. On the basis of unpublished and published statistics it has been possible to construct more detailed time series than those which have been used previously.

\section{The development of infant mortality}

\section{General features}

Figure 1 provides us with a general idea about the development of infant mortality starting from the middle of the 18 th century. One can see that infant mortality has been falling ever since. It is certain that the Finnish population statistics give somewhat too low infant mortality rates (IMRs) especially in the 18 th century (see Pitkänen 1977), but in any case the decline has been relatively slow up to the latter half of the 19th century. Starting from the 1880 s the decline accelerated considerably and, in fact, already between the 1870 s and the First World War the decline was considerable, about 30 percent. ${ }^{2}$ Thus, the interwar period is not the point of time when infant mortality started to fall rapidly, although the decline then somewhat accelerated.

There are, however, two other factors which, no doubt, have both led many

${ }^{2}$ Recently V. Rasila has emphasized the great decline, which occurred between the 1870 s and the beginning of the 20th century. Unfortunately his observation is based on an erroneous (much too high) infant mortality rate in the 1870 s (see Rasila 1982, 133). 
F i g u r e 1. Infant mortality rates (IMRs) in Finland 1751-1975 and in the Finnish cities 1811-1975 (log. scale).

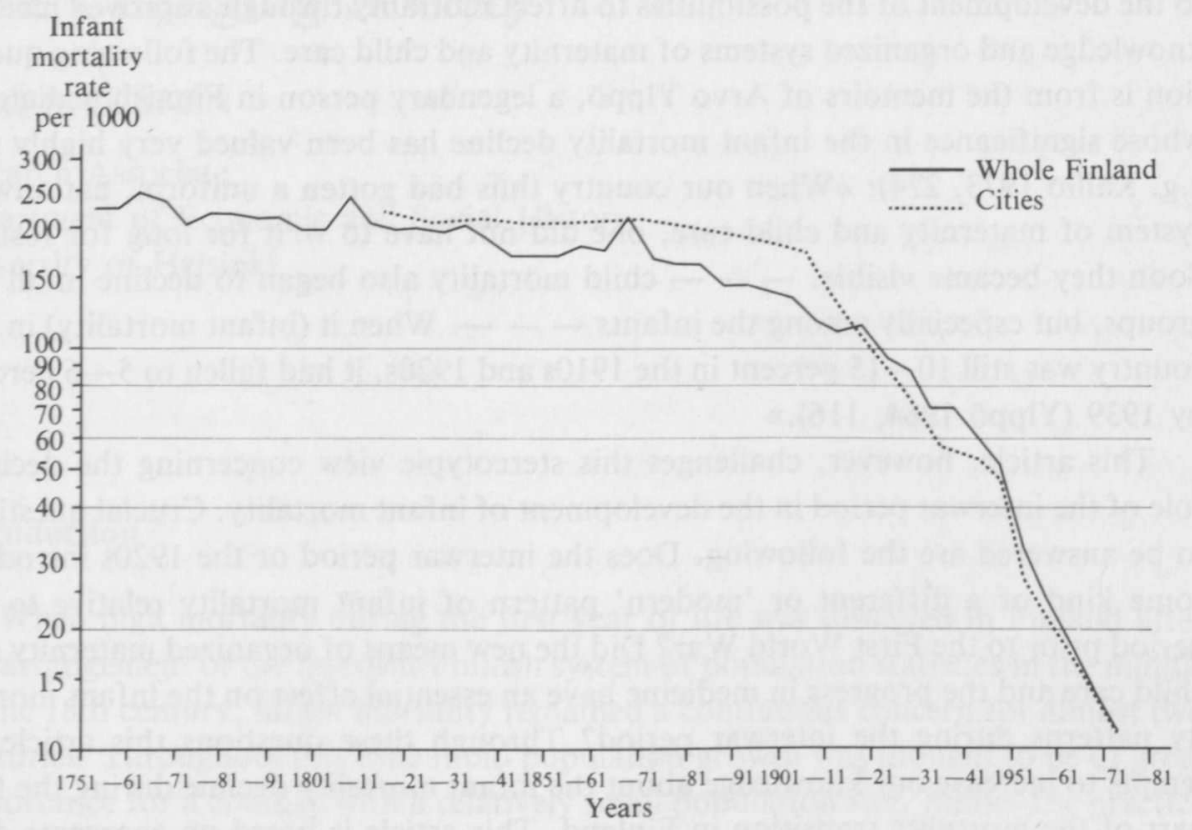

Sources: Strömmer 1969, Appendix Table I; Tunkelo 1948, 25; OSF VI A, vital statistics 1946-75.

scholars to stress the importance of the 1920s in the development of infant mortality. Before that decade the IMRs had not fallen below the "magical» point of 100 infant deaths per thousand live births - not even for a single year. Secondly, in the 1920 s average infant mortality in the cities fell below the level prevailing in the rural areas. The latter change has been seen as proof of the effect of the improvements in the maternity and child care systems, which had taken place in the 1920s and which were more evident in the urban areas (see Tunkelo 1948, 25; Lento 1967, 17; Huttunen 1968, 556).

As F. W. Westerlund had shown already in 1889 in his classical infant mortality study, there are differences in infant mortality, not only between urban and rural areas, but also between male and female children and between legitimate and illegitimate children. Infant mortality data from 1851 to 1940 in Appendix Table 1 takes into consideration all these variables. The rates are also presented in Figure 2.

Male excess mortality is a well-known phenomenon also among infants and this is clearly visible in the Finnish data throughout the period. Male excess mortality is, however, much smaller for illegitimate children, especially in the cities. A slight tendency of increase in male excess mortality can be seen when infant mortality declines. 
F i g u r e 2. Infant mortality rates in the cities and the countryside for legitimate and illegitimate children $1851-1940$, by sex

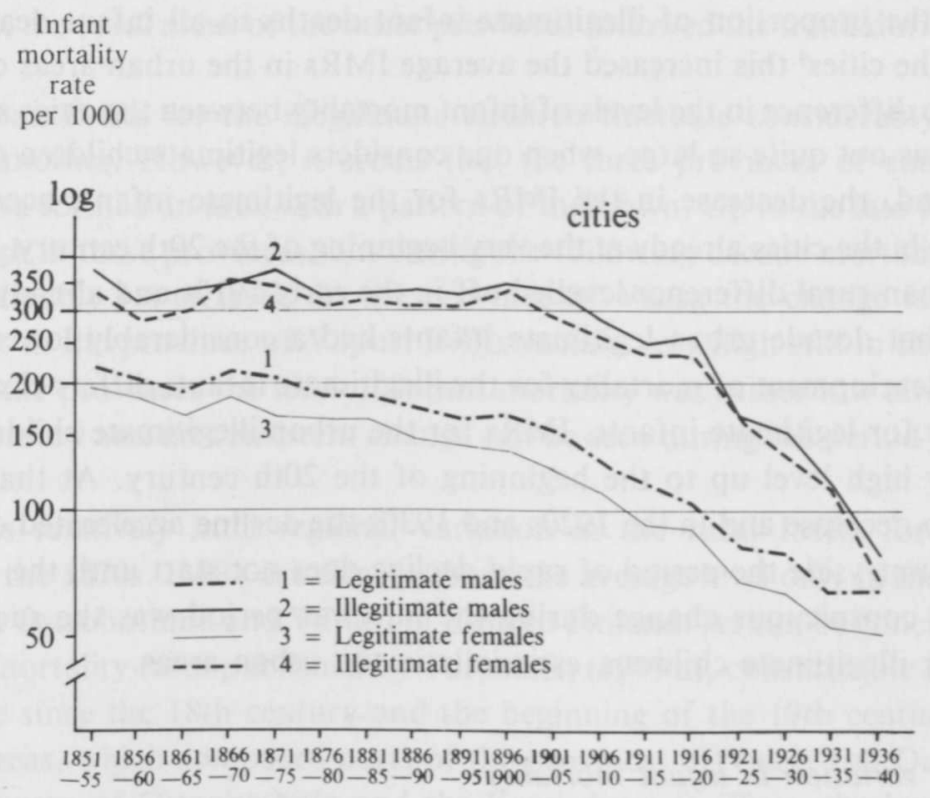

\footnotetext{
Infant mortality

rate

per 1000
}

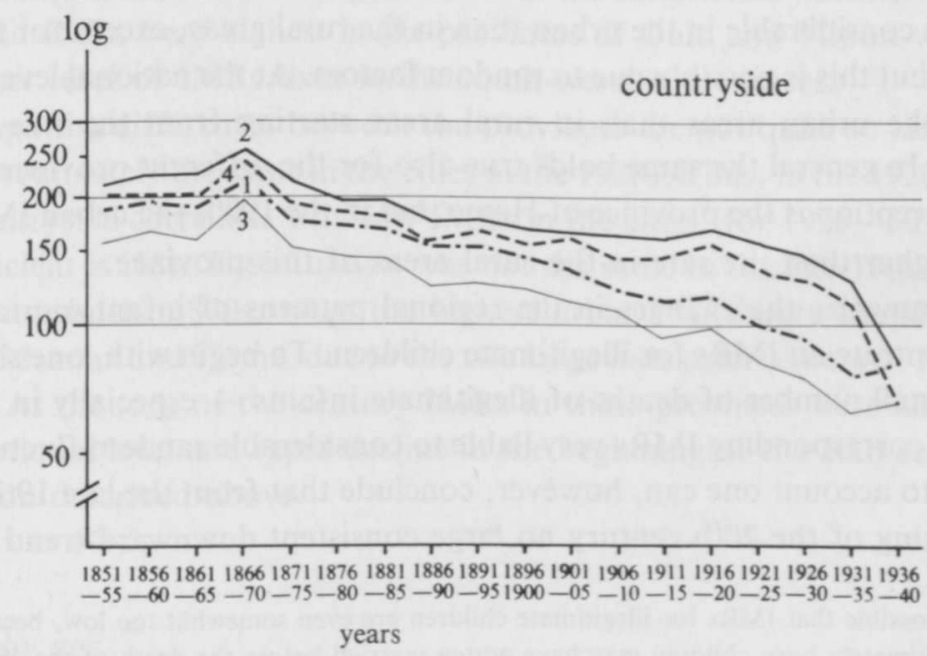

Sources: See Appendix Table 1.

Rates for the years $1851-77$ include only the Lutheran population. 
It is very informative to examine rural-urban differentials separately for legitimate and illegitimate children. In the 19th century and in the beginning of the following century IMRs were highest among illegitimate children in the cities. ${ }^{3}$ Because the proportion of illegitimate infant deaths to all infant deaths was very large in the cities ${ }^{4}$ this increased the average IMRs in the urban areas considerably. Thus, the difference in the levels of infant mortality between the cities and the countryside was not quite so large, when one considers legitimate children only. ${ }^{5}$ On the other hand, the decrease in the IMRs for the legitimate infants accelerated considerably in the cities already at the very beginning of the 20 th century. Consequently the urban-rural difference levelled off in the early 1910s and already in the latter half of that decade urban legitimate infants had a considerably lower IMR.

The development of mortality for the illegitimate infants differs clearly from the mortality for legitimate infants. IMRs for the urban illegitimate children remained at a very high level up to the beginning of the 20th century. At that time IMRs started to decrease and in the 1920s and 1930s the decline accelerated considerably. In the countryside the period of rapid decline does not start until the 1930s. Thus, the most conspicuous change during the interwar period was the sudden drop in IMRs for illegitimate children, especially in the urban areas.

\section{Regional variation in infant mortality}

In order to get a general view of the regional variation in infant mortality, IMRs have been calculated for certain cross-section periods by provinces. The rates are presented in Appendix Table 2. The general trends in the IMRs are very much alike in all of the provinces. IMRs for legitimate children decline considerably in every province both in the cities and in the countryside, and everywhere the decline has been more considerable in the urban than in the rural areas, except for the province of Vaasa, but this is possibly due to random factors. At the national level IMRs were lower in the urban areas than in rural areas starting from the five-year period 1916 - 20. In general the same holds true also for the different provinces. The most marked exception is the province of Häme, but in the 1920s the urban IMR was only slightly higher than the rate in the rural areas of this province.

To summarize the changes in the regional patterns of infant mortality, I shall first concentrate on IMRs for illegitimate children. To begin with, one should notice that the small number of deaths of illegitimate infants - especially in the cities makes the corresponding IMRs very liable to considerable random fluctuation. Taking this into account one can, however, conclude that from the late 19th century to the beginning of the 20th century no large consistent downward trend is visible in

\footnotetext{
${ }^{3}$ It is possible that IMRs for illegitimate children are even somewhat too low, because some parents of illegitimately born children may have gotten married before the death of the children.

${ }^{4}$ E.g. in $1871-7523 \%$, in 1896-1900 $19 \%$ and in 1916-20 $28 \%$.

5 This is especially true, if one takes into consideration the possible effect of the large migration movement from rural to urban areas. It is possible, namely, that some infants who died in the cities had actually been born in the rural areas.
} 
the rural areas. In the 1920 s the rates dropped to a considerably lower level in the provinces of Uusimaa, Turku and Pori and Häme, which included the central parts of the industrialized Finland. Concluding from the drastic decline in the national rural IMRs, the rural areas of the other provinces followed the trend during the next decade.

The urban IMRs for the illegitimate children fluctuate considerably from one period to another. However, it seems that the three provinces of south-western Finland have formed an area with a pattern of their own. Up to the late 1910s IMRs are very high in these provinces, but during the following decade mortality dropped to a considerably lower level. In the province of Vaasa the change is somewhat similar, but in the province of Viipuri IMRs remain very high still in the $1920 \mathrm{~s}$. In the rest of the provinces the level of infant mortality was rather low already in the late 19th century and no consistent change can be seen during the period under consideration.

There is relatively little regional variation in the rural IMRs for legitimate children in the 1870 s. IMRs are clearly above the average level only in the provinces of Vaasa in Ostrobothnia and Viipuri in Eastern Finland. As can be concluded from the infant mortality rates published by Turpeinen (1979 a), considerable decline had taken place since the 18 th century and the beginning of the 19th century in those northern areas, which composed parts of the provinces of Vaasa and Oulu (mainly the coastal area of Ostrobothnia and the Kemi district). Thus, the large regional variations which had existed previously, had already levelled off to a great extent. But, although rural infant mortality fell considerably between the $1870 \mathrm{~s}$ and $1920 \mathrm{~s}$ in every province, the regional variation did not grow relatively smaller. In the 1920 s the previously mentioned three south-western provinces clearly showed the lowest IMRs. The infant mortality rates grew towards the eastern and northern parts of the country and IMRs were highest in the provinces of Oulu and Viipuri with about a $50 \%$ higher level of IMRs than in the south-western provinces.

Although the differences between the provinces are not quite so large, the pattern is approximately the same in the cities in the 1920 s. Thus, in the 1920 s low IMRs in the countryside correlates with low IMRs in the cities (for 1926-30 the correlation coefficient is .88 ). The situation was not the same in the late 19th century and especially not in the 1870 s, when the highest urban IMRs were found in the provinces of Uusimaa and Häme, due to the two large industrial centers of Helsinki and Tampere. At the turn of the century IMRs in these provinces were already at the average national level and rapid decline in the beginning of the 20th century led to the situation described above.

\section{Mortality by age}

Starting in 1878 the Finnish population statistics also include information concerning the age structure of the deceased infants. Appendix Table 3 includes mortality rates for three age groups, those who died during the first week, 2nd-4th week 
and 2 nd -12 th month of life, from 1881 to 1940 . The age pattern of infant mortality is quite diversified in the late 19th century, when one looks both at the legitimate and illegitimate children separately in the cities and the countryside. Concerning the legitimate children, there are no considerable urban-rural differences in mortality during the first week and the 2 nd -4 th week of life, although rural rates are slightly higher. The difference in mortality during the 2 nd -12 th month is also not very large, but it is in the opposite direction. Rural illegitimate children also had slightly higher mortality during the first week of life, but infant mortality at other ages was considerably higher for urban than rural illegitimate children.

When one considers only legitimate children, mortality declined in all age groups up to the beginning of the 20th century. After that mortality during the first week of life came to a standstill and urban mortality for this age group even started to rise and consequently, in the $1930 \mathrm{~s}$, urban rates are higher than those of the rural areas. But, the infant mortality decline in other age groups accelerated at the turn of the century and the rates dropped somewhat faster in the cities.

It is not easy to make conclusions about the changes in the age pattern of the illegitimate children, because the rates fluctuate very heavily from one five-year period to another. The development in mortality during the first week of life resembles that of the legitimate children in the sense that it does not show any consistent decline, although the rates are exceptionally low during the last five-year period. For other age groups mortality of illegitimate children decreased considerably during the interwar period. The decline was more profound in the cities and consequently higher mortality for the urban infants levelled off in the 1930s.

\section{The infant mortality data and the interwar period}

The infant mortality data presented above does not in itself support the view that infant mortality patterns would, in general, have undergone some essential changes just between the 1920s and the Second World War. The most drastic change was the rapid decline in IMRs for illegitimate children, to which question we shall return later on in this paper. But, the IMRs for legitimate children had started to decline continuously already during the last decades of the 19th century. In addition, there are two slight - although clear - thresholds, especially if one excludes the stagnating mortality during the first week of life. The first one is during the first decade of the 20th century and the other one is in the beginning of the 1920 s, even if one takes into consideration that the late 1910 s was a period of war with its possible negative effects on infant mortality. However, if one looks at the yearly figures, it can be seen that the mortality level which prevailed in the early 1920 s was reached already by the turn of the decade. It would be difficult to attribute this change in the national rates to the new system of maternity and child care, the development of which had hardly yet even begun.

One factor which is clearly visible during the interwar period is the regional pattern, in which the three south-western provinces - in average the most developed 
areas in Finland - showed the lowest IMRs in the late 1920s especially for legitimate infants. From the reports of the Central Medical Board one can see that although infant mortality had declined since then in all the provinces, a similar regional pattern existed also in the late 1930s. Roughly speaking, the level of infant mortality was higher the further one moved away from the central area towards the northern and eastern parts of the country. The highest IMRs were in Karelia, on the northern side of Lake Ladoga and in northern Finland, especially in Lappland (OSF XI, Reports of the Central Medical Board 1935-38).

The lower IMRs in the urban areas within the provinces and the regional pattern described above could - and indeed have been regarded as proof of the significance of the nationwide maternity and child care system, because the availability of these services was best in the cities and in the densely populated central rural areas (see Komiteanmietintö (Committee report) 1939:9, 70). But, one must notice that this regional pattern had also taken shape already during the two first decades of the century, before the interwar period, and this development was merely completed in the 1920 s and 1930s.

\section{Perinatal mortality}

One would have also expected that when the nationwide maternity and child care system began to be developed, mortality during the first week of life would have decreased. However, the decrease which is visible for the legitimate children took place already around the turn of the century, but it did not continue during the interwar period. Mortality during the first week of life can be connected with stillbirths, because they both are caused to a great extent by the same factors, conditions which effect the mother before and during childbirth, the child's congenital debility etc. Thus, there is a possibility that the development in maternity and child care would have led to a considerable decrease in the number of stillbirths, but consequently also to a stagnation or even increase in mortality during the first week of life, although perinatal mortality as a whole would have diminished. On the other hand it is possible that still in the late 19th century some children who had died soon after birth were registered as stillbirths, although they actually were live births. Thus, it is important to examine the whole perinatal mortality ${ }^{6}$ and for this reason stillbirth ratios were also calculated for $1881-1940$ (Table 1).

At first stillbirth ratios decrease around the turn of the century in all the groups, but the downward trend stagnates in the beginning of the 20th century and is followed by a clear upward trend for illegitimate children up to the late 1930s. Thus, both mortality during the first week of life and stillbirth ratios underwent - roughly speaking - similar development. The conclusion must be that the stagnation in mortality during the first week of life can hardly be 'explained' at the national level by the decreasing number of stillbirths.

6 This does not totally eliminate the danger caused by changing practices in registration, because in older times the difference between a stillbirth and a miscarriage may have been very vague. 
$\mathrm{T} \mathrm{a} \mathrm{b} \mathrm{l} \mathrm{e} \mathrm{1.} \mathrm{Stillbirth} \mathrm{ratios} \mathrm{in} \mathrm{Finland} \mathrm{for} \mathrm{legitimate} \mathrm{and} \mathrm{illegitimate} \mathrm{children}$ (per 1000 births) in the cities and the countryside, 1881-1940. CITIES

$\begin{array}{lcccc}\text { Year } & \begin{array}{c}\text { Legiti- } \\ \text { mate }\end{array} & \begin{array}{c}\text { Illegiti- } \\ \text { mate }\end{array} & \begin{array}{c}\text { Legiti- } \\ \text { mate }\end{array} & \begin{array}{c}\text { Illegiti- } \\ \text { mate }\end{array} \\ 1881-85 & 28.3 & 61.1 & 26.2 & 44.5 \\ 1886-90 & 29.6 & 50.1 & 26.2 & 46.9 \\ 1891-95 & 29.9 & 59.3 & 25.2 & 43.7 \\ 1896-00 & 27.1 & 49.5 & 25.0 & 41.3 \\ 1901-05 & 23.9 & 47.7 & 23.8 & 40.0 \\ 1906-10 & 25.2 & 45.7 & 22.9 & 39.5 \\ 1911-15 & 24.2 & 36.9 & 24.0 & 40.8 \\ 1916-20 & 24.0 & 51.3 & 23.6 & 44.6 \\ 1921-25 & 24.8 & 54.9 & 24.2 & 47.4 \\ 1926-30 & 25.3 & 55.3 & 24.5 & 45.5 \\ 1931-35 & 23.5 & 56.5 & 24.6 & 47.8 \\ 1936-40 & 19.1 & 38.5 & 22.2 & 38.9\end{array}$

Sources: OSF, Vital statistics $1881-1940$.

A plausible explanation for the favorable period in the development in perinatal mortality around the turn of the century would be that the proportion of childbirths, which either took place in the maternity hospitals or were assisted by a midwife, started to increase rapidly from the late 19th century onwards (SYF 1941):

$\begin{array}{llllllllllll}\begin{array}{l}\text { Year } \\ \begin{array}{l}\% \text { of all } \\ \text { child- }\end{array}\end{array} & 1886 & 1895 & 1900 & 1905 & 1910 & 1915 & 1920 & 1925 & 1930 & 1935 & 1938 \\ \text { births } & 15 & 26 & 32 & 39 & 46 & 45 & 54 & 66 & 72 & 83 \\ \end{array}$

But, the proportion of such childbirths continued to rise also after the stagnation in perinatal mortality. This does not, however, have to mean that the increased use of maternity hospitals or midwives would have necessarily been useless or would have even had a negative effect. Probably there were some factors interfering with favorable development after the beginning of this century. Attention has been drawn to the fact that perinatal mortality seems to be higher for first-born children (Mustonen et al. 1976, 15; Söderström 1933, 524 and 535). This is probably one important reason for the differences in perinatal mortality between legitimate and illegitimate children, because the latter in most cases were first-born. ${ }^{7}$ When marital fertility started to decline in Finland from 1910s onwards, the proportion of first-born children indisputably increased (see Söderström 1933, 532). Still, I would hesitate to explain the stagnating perinatal mortality with this kind of effects of declining fertility, because on the other hand also children with high parity/old

\footnotetext{
7 There were probably also other reasons for this difference, e.g. hard work for the unmarried women still during the last phase of their pregnancy.
} 
mothers have high mortality (Bardy and Kauttu 1966, 128-129; Tudeer 1922, 164) and their proportion tends to decrease along with the fertility decline.

The most plausible explanation of the stagnating perinatal mortality is the increased use of illegal abortions. As in many other countries, attention in Finland was also drawn during the interwar period to the phenomenon that the use of illegal abortions had grown enormously from 1910s onwards. The yearly number of illegal abortions was estimated in the 1930 s as some tens of thousands ${ }^{8}$ (Apajalahti 1939; Pelkonen 1939). Illegal abortions were used mainly by unmarried women, but at least in the urban areas they were also used more and more by married women. As Söderström (1933) has shown perinatal mortality was very high for children who were born prematurely. He also showed that the proportion of premature births was increasing in Helsinki in the beginning of the 20th century and this increase can be connected with the growing number of women who had tried to induce an abortion. This factor would fit well with the changing features in perinatal mortality, because an upward trend in the rates for illegitimate children is visible just at that time, when illegal abortions probably became more common. In addition, mortality during the first week of life increased also for legitimate children in the urban areas and finally exceeded the level prevailing in the rural areas. These are probable indicators that illegal abortions may well have been the main reason why the amelioration of maternity and child care failed to diminish mortality during the first week of life after the beginning of the 20th century. The positive results of the increasing use of professional assistance at childbirth, however, became apparent in the first place in decreasing maternal mortality. Maternal death rates had remained at the same level for a long time, until they started to decline at the end of the 19th century, at first more rapidly in the cities (see Leidenius 1932). In addition, in the late 1930s infant mortality for legitimate children by endogenous causes (premature births, congenital malformations, birth injuries etc.) was on the average slightly lower in the southwestern parts of the country, where professional assistance was more frequently used and its quality may have been better. In fact, mortality by endogenous causes was to a considerable extent responsible for the regional variation in the late $1930 \mathrm{~s}$ (OSF VI, causes of death 1936-39).

\section{Preliminary conclusions}

In order to summarize the conclusions reached so far, one can say that no essential changes in the infant mortality patterns which could be attributed particularly to the foundation of the organized maternity and child care system have been found. The timing of the decline and the lowest IMRs in the more developed regions would seem to give a better justification for explanations which attribute the infant mortality decline to the improvements in the standard of living (see e.g. Rasila 1982, 134; Ahvenainen 1982,312$).{ }^{9}$ This factor can, of course, include a large amount of par-

\footnotetext{
${ }^{8}$ Simultaneously the yearly number of live births ranged from 65 to 78 thousand.

${ }^{9}$ The results obtained by Heikkinen $(1981,418)$ indicate that on the average $n$ the material standard of living» was rising already between the $1860 \mathrm{~s}$ and $1910 \mathrm{~s}$.
} 
tial factors, but probably the scholars have usually had factors on their minds such as better nutrition, better housing conditions, better hygiene, medical progress, but also better supply and access to health care (see Valkonen 1980, 23-24).

But, can we really claim to understand the infant mortality patterns and changes in them by using explanatory factors like this alone. As Turpeinen $(1979 a, 15)$ has remarked, the regional variation in infant mortality did not correlate well with the level of prosperity in the 18 th century and early 19th century. He has also marked that in certain regions very high IMRs dropped to a considerably lower level during the late 18 th and early 19 th century. This development can hardly be attributed to a corresponding rise in the standard of living.

On the other hand, rural IMRs for legitimate infants clearly decreased already during the last decades of the 19th century. Although the material standard of living was rising, it varied unevenly between the social groups at the expense of the rural proletariat (see Heikkinen 1981, 418-419), whose proportion was still growing during the latter half of the 19th century. Now, if groups with a lower standard of living/social status had continuously higher infant mortality ${ }^{10}$ in comparison with the groups of higher standing, the rise in the standard of living as a sufficient explanation does not seem any more self-evident. The same disquieting thoughts also pertain to the cities. One should think that during the large migration movement to the cities, social problems would have been intensified. Although actions were taken in certain cities to improve sanitary conditions, could these actions really have caused the decrease in urban IMRs in so many provinces of the country during the late 19th century. One can also remark that between the 1870 s and the late 1900 s the relative decrease in rural IMRs was about the same size in all the provinces. If the decline should be attributed to factors related to the standard of living, it is suspicious that the effects of these factors would have been felt to such a similar extent in the different parts of the country. Finally, it is hard to find such drastic social or economic changes in the conditions of the unwed mothers that they would explain such a sudden drop in the IMRs for illegitimate children, which took place during the interwar period.

All the problems presented above imply that it is at least a simplification, and perhaps even misleading, to explain the phenomenon of the Finnish infant mortality decline only with factors such as the rise in the standard of living or the foundation of the maternity and child care system. The analysis of perinatal mortality has shown that the factors effecting infant mortality may be very complicated and the significance of different factors may have varied in the course of time. Thus, the factors mentioned above may have had a large significance during some limited period of time, but in order to judge this the decline in infant mortality should be examined in totality.

10 This assumption has often been confirmed by empirical studies, but not without numerous exceptions. Thus, these observations also make the absolute correlation between higher economic level and lower infant mortality questionable (see Brändström and Sundin 1981, 76). 


\section{An attempt at interpretation}

\section{Basic considerations concerning child care}

My starting point is that in order to be able to understand the infant mortality patterns in the past, one has to understand the role of infant mortality in the demographic system and in the minds of the people. High fertility in pre-industrial societies has often been seen as an adaptation to high infant (and child) mortality. However, different views, which has been summarized by van de Walle and Knodel (1980, 25-27) have also been presented during the last few years. The evidence they refer to indicates that »deaths of children were often welcomed as relief from the onus of parenthood. At the least, mothers and fathers were frequently indifferent to the loss of a child». The authors have suggested that frequent births and high fertility were not necessarily signs of parents' wishes to have many children, but merely a part of nature's order that was practically unavoidable. In this situation high infant and child mortality was welcomed as a way to limit family size. Mortality was, however, not often assisted by outright infanticide, but rather with neglect and improper child care practices.

Evidence is not lacking which would indicate that attitudes toward children and child mortality were very similar in Finland also. Such attitudes were frequently reported during the latter half of the 19th century by district physicians, ministers of the church and other people with higher education. In 1857 , for example, the physician of the Jyväskylä district wrote that "poor, rude parents are very pleased with the loss of their child and they thank God, who has taken the child away from this bad world and thus lessened the burden of the parents» (FLH VII, 318-319). In 1859 the physician of the Helsinki district reported that "not seldom are parents pleased if their child dies, and often they do nothing in case of illness to keep the children alive» (FLH VIII, 11). In a newspaper article from 1886 the following is reported: "If you go to the common folk in the countryside or to the laborers of the cities, you are told that this family or another or their child has been so lucky that the child passed away already at a very young age. Neither is it unusual that the parents wish that their children would pass away, especially if they happen to have several of them» (Aamulehti 1886, nr 61).

Although such statements are most frequent during the latter half of the 19th century, similar statements do exist from other periods, too. In a Royal Letter from 1752 it is stated that "the common people in the whole kingdom and especially in Finland - - - takes rather poor care of their children and regard them more a burden than a treasure, which should be taken care of with all possible means ( $\mathrm{Hjelt}$ 1892, 281-282). A similar complaint is in a pamphlet published in 1756 in order to stress the importance of proper child care (Pienden lasten tarpellinen holhomus $-\ldots-1756,4)$. A description concerning the city of Turku from 1783 included the following statement: "The largest part of them (the common people) are pleased with a child's death, as soon as they have more than one (Tidningar utg. af et sällskap i Åbo 1783, nr 25). 
Numerous statements with similar views could be presented (see also von Bonsdorff 1975, 235-236), but equally frequent are statements which reflect the fatalistic attitude of the parents toward death. A belief that life and death were in the hands of God was often mentioned. The physician of the Heinola district reported in 1860: "People very seldom seek medical help and the minister is the first one to hear about the illness (of a child), when the burial is being arranged with him. If one discusses this indifference with the parents, the answer can be guessed in advance: 'it was meant to be so', or some other equally fatalistic expression» (FLH VIII, 563).

The statements presented above and others similar to them indicate very strongly that people of the past had a very fatalistic attitude toward death. As a matter of fact, fatalism was probably reflected in the whole sphere of life. People considered their possibilities to considerably affect several aspects of their life as extremely small. This attitude was probably also supported by the view that the death of some of their children was actually a relief for the parents (at least in the case of small children, see von Bonsdorff 1975,236 ). It indeed seems that people did not necessarily want to have many children. This is reflected also in several proverbs. 'Children are God's gifts' was taught by the church, but people often had their own additions: Children are God's gifts, but I wish there would not be so many of them (FLS Pyhäranta. H. Vinter 616. 1915). ${ }^{11}$ The most natural solution in this situation was that Death was able to reap its harvest without considerable resistance.

Thus, the fatalistic attitude toward the death of their children may have merely been a justification parents used so that they could neglect the proper care of their infants and continue with such improper practices, even when these were condemned by the physicians and the authorities. ${ }^{12}$ Von Haartman, Director General of the Central Medical Board, wrote in 1844: „They say that children are happier in heaven; this comforting saying is true, but can concern only those, who can say it in good faith. This is because the very same words are only blasphemy against religion and the teaching of salvation from the mouths of those parents, who through their own carelesness have caused the death of their child $--\rightarrow$ (von Haartman 1844, 9-10). This does not, however, necessarily mean that the parents consciously perceived that they acted with an intention to kill their children in order to relieve their own burden. The church had taught that God did what he saw was

11 It is worth mentioning that when a questionnaire was sent in 1914 mainly to the physicians and the midwives (the latter were in most cases women of the common people), one question in it was: Do people want to have many children? The replies were amazingly unanimous. In most cases it was stated that people did not want more than a few children. A surprisingly large amount of the replies included bold statements that people did not want to have children at all and that sterile women were therefore envied (FLS, Duodecim 1950). The latter kind of replies are possibly at least partly reflections of disapproval against the idea of efficient family limitation through birth control, which had become a question current just at that time. But, the desire for small families seems to be a phenomenon with deeper roots.

12 Even the long lasting resistance to smallpox vaccination (see von Bonsdorff 1975, 236 and Westerlund 1891,16 ) could be viewed from this point. 
best, and people were able to adapt this teaching very easily to infant care and conclude that the death of an infant was God's will, whatever their child care was like (see e.g. Hämäläinen 1861, nr 25). Life in the past was a hard struggle, and the death of an infant could be viewed as God's wish to save the child from the miseries of this world. By adopting this view the parents' actions and their conscience could be in harmony.

\section{Child care and infant mortality decline in pre-industrial society}

Are we then able to explain e.g. that the variation in infant mortality was due to differences in child care practices, or that the decline in infant mortality was due to the changes in people's attitudes towards child care. It is obvious that we cannot tell to what extent improper child care practices have affected the level of infant mortality in different regions or during different time periods. There is, however, one factor of child care which has a considerable effect on infant mortality - the breast-feeding of infants. It has been proved conclusively that the practice of not breast-feeding tends to raise considerably the level of infant mortality. In addition to the fact that breast milk is nutritionally ideal, breast-feeding also provides some immunity from diseases. The dangers involved with artificial feeding naturally depend to a considerable extent on the nutritional and hygienic quality of substitute foods and overall sanitary conditions (Knodel 1977, 1112-1113). One can see from contemporary writings that these factors certainly were far from satisfactory in the societies of the past (see e.g. Brändström and Sundin 1981, 90-92).

The relationship between breast-feeding and infant mortality was also realized in Finland by the physicians and other members of the educated classes. »It is wellknown that in Ostrobothnia the bad habit commonly prevails that children are fed with cow's milk and milk gruel (through a horn and a teat) instead of using breastfeeding and breast milk. But, statistical tables also show that in no other province is infant mortality as high» (Tidningar utg. af et sällskap i Ảbo 1785, Bihang, $150-151)$. During the 18 th and 19 th century it was very frequently reported that in several parishes in the coastal area of Ostrobothnia and in the Kemi district women did not breastfeed their infants (see e.g. Hjelt 1892, 282-283; von Haartman 1844, $4-5)$. Students of that time noticed that the areas with the highest infant mortality rates were these very same areas. The conclusion that neglect of breast-feeding contributed to higher IMRs in Finland is acceptable also according to modern knowledge. This view is also divided by Lithell (1981) and Turpeinen (1979a). ${ }^{13}$

13 Turpeinen, however, leads one to understand that students in the past have seen the use of a horn in itself as the cause of high infant mortality. He states that this whorn theory" persists, since he showed that the real danger laid win the increased chance of infection transmitted from it (the horn) to the child" (Turpeinen 1979 a, 14). Turpeinen does not give a significant role to such substitute food as cow's milk in itself (Turpeinen 1979 b, 68), but claims that the most significant factor was the floodwater (containing germs etc.), which in the spring polluted the water in the wells. This water was used for washing the milking dishes and the feeding horn, for example, and this way infection was transmitted to children. According to Turpeinen this caused the mortality peak during the summer months (see also 
The effect of artificial feeding on infant mortality has also depended to a great extent on the age when the child was weaned. If artificial feeding was started already during the very first days, the consequences may have been very severe. If the substitute food was improper - as reports of the time clearly show - the disturbances of the stomach, especially diarrhoea, were lethal to many children already during the first weeks of life (see Brändström and Sundin 1981, 92). But, even after that age, especially during the 2 nd -8 th month of life artificial feeding to a great extent promoted mortality from intestinal diseases (see Alho 1915, 6-9), the most important causes of death of infants in areas with high IMRs. Also the general state of health was undoubtedly poorer with artificially fed infants.

The advantages of breast-feeding were probably to some extent lessened, if the child was fed with artificial food in addition to breast milk (Knodel 1977, 1112). The writings of the time indicate that still in the late 19th century it was more a rule than an exception that children received mixed feedings all over the country. The food given to the infants were commonly judged by the physicians as highly improper (FLH VII, 581; FLH VIII, 124 and 451; Ignatius 1858, 146-148). This is possibly the reason why disturbances of the stomach seem to have been important causes of infant deaths also in those areas where children were commonly breastfed (see e.g. FLH VIII, 563-564).

Thus, it seems possible that the regional variation in infant mortality was due to a considerable extent, at least in the 18th and 19th century, to child care practices. ${ }^{14}$ If this is true, then one would also expect that the decline in infant mortality was caused by changes in these practices. Do we have any proof that this would be the case? Turpeinen has shown that in the parish of Koivulahti in Ostrobothnia the IMR in 1749-73 was as high as about 550 (per 1000 live births), but by $1841-50$ it had reduced by $50 \%$. He has suggested that this reduction is due to the increased use of breast-feeding (Turpeinen 1979a). Turpeinen has not been able to show any direct proof that breast-feeding or other child care practices would

Turpeinen 1978). These views can be criticized from several points. First of all, with a few exceptions the students of the time did not stress that the horn, but the habit of not breast-feeding and improper substitute foods were the prime factors involving danger. The horn was an instrument, which was used in fact all over Finland, when the mother did not want or was not able to breastfeed her child. Criticism was caused by the habit that the horn was seldom washed (see e.g. Brändström and Sundin 1981, 92; Westerlund 1889, 623; FLH VII, 309 and 676; FLH VIII, 469-470) and unnecessarily used. Secondly, in my opinion Turpeinen missed the main point with his »floodwater hypothesis». The peak in mortality during the summer months (highest values in July and somewhat lower in June and August) was undoubtedly caused by digestive disturbances (mainly diarrhoea). The phenomenon seems to me to correlate better with changes in temperature. The floodwater would have polluted the wells already in May; also rains during the fall would have flushed the waste material from the surface of the ground into the wells. In the hygienic conditions of the past, water was only one source of micro-organisms e.g. in cow's milk and the warm season forwarded the increase of e.g. bacteria and foodstuffs were easily spoiled. One cannot even be very optimistic about the overall state of health of the dairy stock. Besides, one should note the possibility that during the summer season children were more rarely breastfed, because of women's work outside the farmyard (Lithell 1981, II: 19; Westerlund 1891, 15; FLH VII, 303).

${ }^{14}$ Naturally also other factors, e.g. population density, have somewhat affected the level of IMRs in different regions (see Brändström and Sundin 1981, 98). 
have changed in Koivulahti, although some actions had been taken in Finland by the authorities to encourage breast-feeding. However, generally complaints were still made in the 19th century that actions like these were mostly met with the stubborn attitudes of the people (von Bonsdorff 1975, 235) and the habit of not breastfeeding was continuously reported in Ostrobothnia (see e.g. von Haartman 1844, 4-5; Aspelin 1866, 155; Pohjolainen 1890, nr 12). Although not discussed by Turpeinen, the changes in the age pattern of infant mortality in Koivulahti imply the possibility of changes in feeding practices, especially in early infancy. Probabilities of dying ${ }^{15}$ declined considerably at all ages above one week of age and the decrease was largest in the age groups 8 th -28 th days and 29 th -60 th days. After this decline, the probability of dying during the 8 th -28 th day of life was nearly the same in Koivulahti as in the parish of Pudasjärvi, the parish which Turpeinen had chosen for comparison, because the IMRs there were very low. ${ }^{16}$ The difference in infant mortality between the parishes was largest in the age group 3rd-6th month implying that breast-feeding was not yet very common in Koivulahti.

\section{The case of Ylitornio parish}

A newspaper article was written in 1863 by Albert Heikel, the rector of Ylitornio parish (Helsingfors Tidningar 1863, nr 225). Ylitornio parish in Kemi district was reported by von Haartman in 1844 to be one of those areas, where women did not breast-feed their children. This is also confirmed by Heikel, who tells that when he in 1850 became the rector of the parish, he found that infant mortality there was very high. He also marked that child care was very poor in all respects. The children were quelled by rocking their cradle very heavily until they probably lost consciousness. The children were given quicksilver and alcohol as »medicine». After Heikel had realized this situation, he started to spread information especially about the importance of breast-feeding. His work met first with frustrating-stubborn indifference, but gradually this work started to bear fruit. As a consequence infant mortality started to decline in Ylitornio and the situation became even better than in the chapelry of Turtola, where infant mortality had been lower and child care practices somewhat better (according to von Haartman children were breastfed there (1844).

In order to find out whether infant mortality really had declined in Ylitornio after Heikel became rector of the parish, IMRs for Ylitornio and Turtola were calculated (Table 2).

15 Turpeinen has only given the distribution of infant deaths by age and mortality rates in each age group per 1000 live births, which both basicly give the same information. Approximate probabilities of dying were thus also calculated (for method see note in Appendix Table 3).

${ }^{16}$ Pudasjärvi is, however, not an ideal parish for comparison, because in my opinion it is a parish with obvious deficiencies in the registration of vital events (see Pitkänen 1977, 146-147). 
$\mathrm{T}$ a b l e 2. Infant mortality rates in the parishes of Ylitornio and Turtola in 1811(1821) - 1870 (per 1000 live births).

\begin{tabular}{lcccc} 
& \multicolumn{2}{c}{ YLITORNIO } & \multicolumn{2}{c}{ TURTOLA } \\
Years & $\begin{array}{c}\text { Legiti- } \\
\text { mate }\end{array}$ & $\begin{array}{c}\text { Illegiti- } \\
\text { mate }\end{array}$ & $\begin{array}{c}\text { Legiti- } \\
\text { mate }\end{array}$ & $\begin{array}{c}\text { illegiti- } \\
\text { mate }\end{array}$ \\
$1811-15$ & 355.9 & 136.4 & $\ldots$ & $\ldots$ \\
$1816-20$ & 398.3 & 333.3 & $\ldots$ & $\ldots$ \\
$1821-25$ & 395.6 & 300.0 & 276.9 & 312.5 \\
$1826-30$ & 393.4 & 371.4 & 281.9 & 272.7 \\
$1831-35$ & 491.6 & 342.9 & 282.8 & - \\
$1836-40$ & 462.8 & 307.7 & 261.7 & 200.0 \\
$1841-45$ & 393.8 & 371.4 & 263.2 & 280.0 \\
$1846-50$ & 377.5 & 346.9 & 196.2 & 250.0 \\
$1851-55$ & 253.8 & 210.5 & 158.9 & 90.9 \\
$1856-60$ & 150.6 & 363.6 & 216.2 & 200.0 \\
$1861-65$ & 150.2 & 117.6 & 173.0 & 233.3 \\
$1866-70$ & 192.1 & 320.8 & 160.0 & 166.7
\end{tabular}

Sources: National Archives of Finland, population change tables for Ylitornio and Turtola (microfilms).

The figures presented in Table 2 confirm the information given by Heikel. Before the 1850 s IMRs are very high in Ylitornio and rates for illegitimate children are on the average slightly lower (according to Heikel unwed mothers had to breastfeed their children more often). IMRs in Turtola are considerably lower, although still relatively high. The changes in IMRs after Heikel's arrival in the parish were drastic. Within a short period of time the average IMRs for legitimate children decreased immensely - even below the average level of the Finnish countryside (see Appendix Table 1). Also IMRs in Turtola show some signs of decrease, but in 1856-65 they are higher on the average for legitimate children than in Ylitornio. The decline in infant mortality in Ylitornio was so sudden and drastic that it would be difficult to explain this decline with socioeconomic factors. Thus, the changes in child care practices seem to be the most plausible explanation. This is also confirmed by the physician of Tornio district, who in 1861 wrote: "The infant care practices seem to become better day after day and sour milk as food for the infants looses its position more and more» (FLH VIII, 1116). ${ }^{17}$

The example of Ylitornio indicates that changes in child care practices may have had a considerable role in infant mortality decline up to the late 19th century, although we cannot totally overlook other possible factors, e.g. smallpox vaccinations. Although complaints about poor child care practices were very frequent still during the latter half of the 19th century, there are also several statements which

17 Analysis of the age and seasonal patterns of infant mortality might also confirm the conclusions reached, but this analysis is not possible by using the statistical population tables. However, Brändström and Sundin (1981) have shown that a similar decline in infant mortality had taken place slightly earlier on the Swedish side of the border, in Alatornio, and analysis of the age and seasonal patterns indicates that changes in infant care practices had taken place. 
show that improvements in child care were taking place at the local level (FLH VII, 348; FLH VIII, 144, 981). In addition, when feeding practices were inquired about in 1914 , it seemed as if breast-feeding had become a very common habit practically all over Finland (FLS Duodecim 1950).

It is probable that the development which took place in Ylitornio was to a great extent due to the activity of a single man. It is probable that this is a general pattern. Although several pamphlets concerning child care practices were published during the 18th and 19th century (Pienden lasten tarpellinen holhomus 1756; Om späda barns uppfödande 1802; von Haartman 1844; Lönnrot 1859; Abelin 1875 and 1879 etc.) it seems that it was very difficult to reach the common people with written information. One such pamphlet was distributed in the $1860 \mathrm{~s}$ and when the physician of Mikkeli district asked an older woman what she thought about the pamphlet, the old woman answered: »Idle gentlemen's foolish talk» (FLH VIII, 981).

In this situation it was probably not the written information, but the individuals, the physicians, midwives and ministers, whose role was decisive in changing attitudes toward child care practices. But, if the death of a child was welcomed with some satisfaction, how were they able to change the situation. From Heikel's writing we can see that the resistance was powerful. The existence of resistance still in the late 1850 s in Ylitornio was also reported by the district physician in 1857 (FLH VII, 348). Thus, it was essential that a person who wanted to change the habits of the people had to work actively and without respite. The ministers (and probably others too) also used pressure with religious arguments. It was emphasized that children were God's gifts, meaning that they were not created in order to be called away almost instantly. It was also easy to reason that God would not have created the organs for breast-feeding unnecessarily. These tactics were used at least by Heikel in Ylitornio. When this kind of reasoning disturbed the deeply rooted fatalistic attitudes of the people and when they realized that not only God's, but also their own actions really might influence whether a child was to remain alive or not, the way was opened towards better child care practices.

\section{The decline in the changing society}

The conclusions reached above indicate that changes in child care practices were to a large extent responsible for the infant mortality decline up to the late 19th century. But, at the turn of the century the regional pattern of infant mortality started to change. Mortality during the 2 nd -12 th month of life was at a standstill for a while during the late 19 th century up to the 1900 s, when it started to decrease very rapidly. We have already seen above that perinatal mortality decreased at the turn of the century along with the increasing use of maternity hospitals and midwives. Do we now have to make a clearcut division between the pre-industrial decline, due to changes in infant care practices, and the "modern" decline due to improvements in sanitary and medical conditions, nutrition, official health care, etc. However, in my opinion this kind of statement would gravely simplify the development of infant mortality. 
To begin with, Waris (1934) has emphasized the importance of actions which were taken in Helsinki during the late 19th century. During this period the sewage and water system spread all around the city. The quality of foodstuffs began to be controlled. Consequently overall mortality declined considerably, and probably not only because of the changing population structure. But, between the 1870 s and the turn of this century infant mortality, even for legitimate children, declined only to a small extent in Helsinki (Heiniö 1937, 180), and even this was probably due to a considerable extent to the decline in perinatal mortality. In 1900 the difference in infant mortality between the main area where the laborer population lived in poorer sanitary conditions and the rest of the city seems to have been surprisingly small (see Waris 1934, 123). Starting from the late 1900 s infant mortality for legitimate children suddenly started to decline rapidly not only in the laborer areas but simultaneously in all parishes of the city. IMRs declined more regularly in the more "wealthy» parishes, but in the areas with a major labor population a clear threshold in the decline can be seen also at the turn of the 1920s (Figures calculated from Statistical Yearbooks of Helsinki 1907-1932).

However, one cannot seriously doubt that the improvements in the factors described above would not have had any positive effects on infant mortality. Actions were taken which probably improved the quality of foodstuffs (especially milk) and drinking water and thus decreased the danger that infection would have been transmitted from them to the infants (see e.g. Waris 1934). When one also considers the overall improvement of nutrition and hygienic conditions, it would hardly be justified to claim that these factors would not have promoted the decline in infant mortality. For example, the improved quality of milk may have affected the decline in mortality from infants' tuberculosis. Some of these factors may have even been partly responsible for the lower IMRs in the more developed areas of the country. But, in my opinion explanatory factors such as these are not sufficient and the changes in society have to be seen in a wider perspective.

Although the Finnish population statistics prior to the late 1930 s do not allow satisfactory calculation of even the main trends in infant mortality by causes, it seems that the infant mortality decline was to a great extent a decline in mortality from intestinal diseases. This is well documented in Helsinki. At the turn of the century, nearly 100 children out of every thousand live births died during the first year of life from gastro-enteritis. If congenital debility is excluded, mortality from other causes was about the same size. By the early 1920s mortality from gastro-enteritis was below 10 per thousand live births, while other causes of death had decreased only by slightly more than 50 percent. When a low mortality from gastro-enteritis was achieved, the infant mortality decline before the Second World War remained relatively small. ${ }^{18}$ The trend was probably quite similar in other parts of the country. Consequently, infant mortality from gastro-enteritis in the late 1930 s was clearly below 10 per 1000 live births with slightly higher rates in northern and eastern than

18 Calculations are based on Alho 1915, Ruotsalainen 1925, Heiniö 1937 and Statistical Yearbook of Helsinki 1950. 
in south-western provinces (OSF VI, Causes of death and vital statistics 1936-39).

Behind this development I would see basically the same factor, which probably affected the infant mortality decline already before the turn of this century, namely propaganda for better child care practices. When infant feeding practices were studied in 1914, one can see that the practices all around the country, although they had undoubtedly improved from older times, were still far from ideal. Children were still fed with improper foodstuffs like coffee and alcohol, and during the first days after delivery children were not always breastfed, but were given full cow's milk (FLS Duodecim 1950). Thus, it is no wonder that the propaganda for better child care practices did not end by the turn of this century. On the contrary, more and more child care guides were published (e.g. Eskelin 1899; Pienten lasten hoidosta 1900 and 1910, Ylppö 1919) and private organizations were founded. Literacy had become much more common and newspapers were commonly read and now written propaganda also reached the common people more easily. For example, in $1920 \mathrm{~s} \mathrm{Ar}$ mas Ruotsalainen wrote a series of articles in Toveritar, a newspaper for women of the labor class (Toveritar 1925, no 19, 1926, nos 2 and 13). Also the use of midwives increased and they were able to effectively spread knowledge concerning child care in the rural areas.

The founding of the nationwide system of maternity and child care during the interwar period can be viewed as a logical continuation of the previous actions, because the means used in educational work had to become more and more efficient in order to achieve continuous results. But, basically the methods used by this organization were the same as in the actions taken before, although improved biological and medical knowledge made it possible to produce better instructions for child care: "In the section of Helsinki called Kallio, which was situated around Lastenlinna, infant mortality decreased within three years from about 16 percent to 3 percent. This comprises the years $1923-26$, when the first station for consultation of small children's care, founded in $1921-\ldots-$, had started to operate. Mothers were not given any financial support, children were not given any special milk. Mothers only got advice from the health sisters and physicians, and the health sisters regularly visited the homes in order to inspect child care practices» (Ylppö 1961, $328-329$ ).

The success of educational work in the 20th century, however, has to be viewed through changes which had taken place in society, starting from sanitary and economic improvements. In addition, we have to remember that the work done in the 18th and 19th centuries met with deeply rooted fatalism and even a desire for the children's death. By the beginning of the 20 th century factors such as the rise in the educational level, the increase in technological knowledge, the birth of mass movements etc. had undoubtedly broken the absolute power of the fatalistic attitudes. Another significant factor is the decline in fertility. Marital fertility declined considerably in the urban areas between the 1910s and the Second World War, but a decrease took place also in the rural areas. ${ }^{19}$ This change may have had

\footnotetext{
19 The description of fertility trends is based on a forthcoming study by the author.
} 
considerable consequences for child care practices. At first, the decreasing number of children per marriage may have meant that it was possible to take better care of the infants, already because the mothers were not exhausted by frequent pregnancies and deliveries. ${ }^{20}$ Secondly, family limitation through birth control is probably connected with a thorough change in the valuation of children. This would mean that it was not only possible to take better care of children, but people also wanted to take better care of them.

One can point out, for example, that the regional variation during the interwar period in low infant mortality for legitimate children correlated not only with a higher average standard of living, but also with lower marital fertility. In addition, infant mortality declined most rapidly in areas where marital fertility also declined rapidly. The development of infant mortality in the educated classes is also noteworthy. Marital fertility for this group remained high up to the 1880 s and infant mortality for children born between the 1840 s and the early 1880 s was about 100 per 1000 live births (the rate may be somewhat underestimated). In the $1880 \mathrm{~s}$ and $1890 \mathrm{~s}$ marital fertility in this group declined considerably through family limitation, and infant mortality for children born in 1885-1905 had fallen to a considerably lower level, to about 45 per thousand live births (for material see Pitkänen 1982).

The rapid decline in infant mortality for illegitimate children can also be viewed from this point. IMRs for these children declined very rapidly during the interwar period. The decline in non-marital fertility started in the Finnish cities in the 1910s and in the rural areas around the year 1930. It is noteworthy that the rapid decline in IMRs started soon after the fertility transition. In my opinion the most plausible explanation for the sudden decline in IMRs for illegitimate children is that birth control, probably to a great extent through abortion (see above), prevented the birth of illegitimate children whose mothers would not have been able or would not have been willing to take care of them. ${ }^{21}$ Thus, illegitimate children were born to a larger extent to women who were able and who wanted to take care of their infants. As a matter of fact, the infant mortality decline observed by Ylppö (see above) in Kallio in 1923-26 (although he seems to exaggerate the change) was mainly due to the decline in IMRs for illegitimate children. It was not, however, a question of a local phenomenon, but a general trend in Helsinki as a whole at the very same time when non-marital fertility declined (Statistical yearbooks of Helsinki 1907-32).

Considering all the factors examined here we can outline a mechanism, which in my opinion helps us to better understand the features of infant mortality decline during the first phase of mortality transition. Educational work and several substan-

20 It is also possible that the increase in small-size families has lessened the possibilities for contagious diseases to reach the infants. This is, however, a complicated matter. For example, the concentration of people in densely populated urban areas may have had the opposite effect. However, it must be regarded very positive that the dwellings were not as overcrowded anymore in the cities.

${ }^{21}$ We know from Helsinki that still at the turn of the century illegitimate infants were very commonly given away to be taken care by other people than their mothers. Mortality among these children was extremely high (Waris 1934, 127-128). 
tial changes in society had removed the fatalistic attitudes concerning death and raised the value of children to such an extent that parents more generally wished to take good care of them. Parents were helped in this by improved sanitary conditions, effective educational work concerning child care practices and the higher material standard of living. The combined effect of these factors should have started to operate just in the early 20 th century. This would explain not only the decimated mortality from intestinal diseases, but also why mortality from several infectious diseases considerably declined. First of all, the general state of health of the infants probably had improved. In addition, the chances of an infant to remain alive in case of illness surely depends somewhat on whether the parents remain indifferent or if they try to promote the recovery of the infant. This view would be worth considering also when the decline in child mortality in general is examined. The model presented would e.g. make it understandable, why infant mortality for legitimate children started to fall in Helsinki so rapidly just during the early 20 th century simultaneously in different sections of the city.

\section{Summary and discussion}

We have seen that the decline in infant mortality has been a longlasting phenomenon in Finland. Up to the late 19th century the decline seems to have taken place mainly in regions where IMRs were exceptionally high in the 18 th century. Between the late 19th century and the Second World War IMRs fell considerably all over Finland and since the beginning of this century more rapidly in areas which were economically more developed (urban areas and the whole south-western part of Finland). The major part of the decline concentrated in the age groups above the age of one week, while the decline in perinatal mortality remained rather insignificant. Consequently the decline is mainly due to exogenous factors. The most significant cause of death had for a long time been the disturbances of the stomach, mainly diarrhoea, especially during the summer season, while respiratory diseases prevailed during the wintertime.

In this paper, infant mortality has been viewed from the point of child care practices, especially of feeding practices. Actions were taken to improve child care and promote breast-feeding and it seems that these actions intensified around the middle of the 19th century, when discussion and research concerning infant mortality became more pronounced. It has been presented in this paper that the improvements in child care due to these actions have probably contributed essentially to the decrease in infant mortality - not only during the 18th and 19th centuries, but also during this century. However, in the 20th century changes which took place in society have undoubtedly given support to educational work and promoted the possibilities to improve child care. Some of these changes have lessened the dangers of indifference in child care (e.g. hygienic conditions) and made the people more susceptible to educational work (removal of fatalistic attitudes, rise in the educational level). One of 
the latter factors is the decline in fertility, which promoted the revaluation of children born in a family. Thus, the decline in infant mortality in a changing society should not be related only to material changes, instead it should be seen that it is related to a thorough change in the whole view of life that people have, caused my numerous intertwined factors in a changing society. 


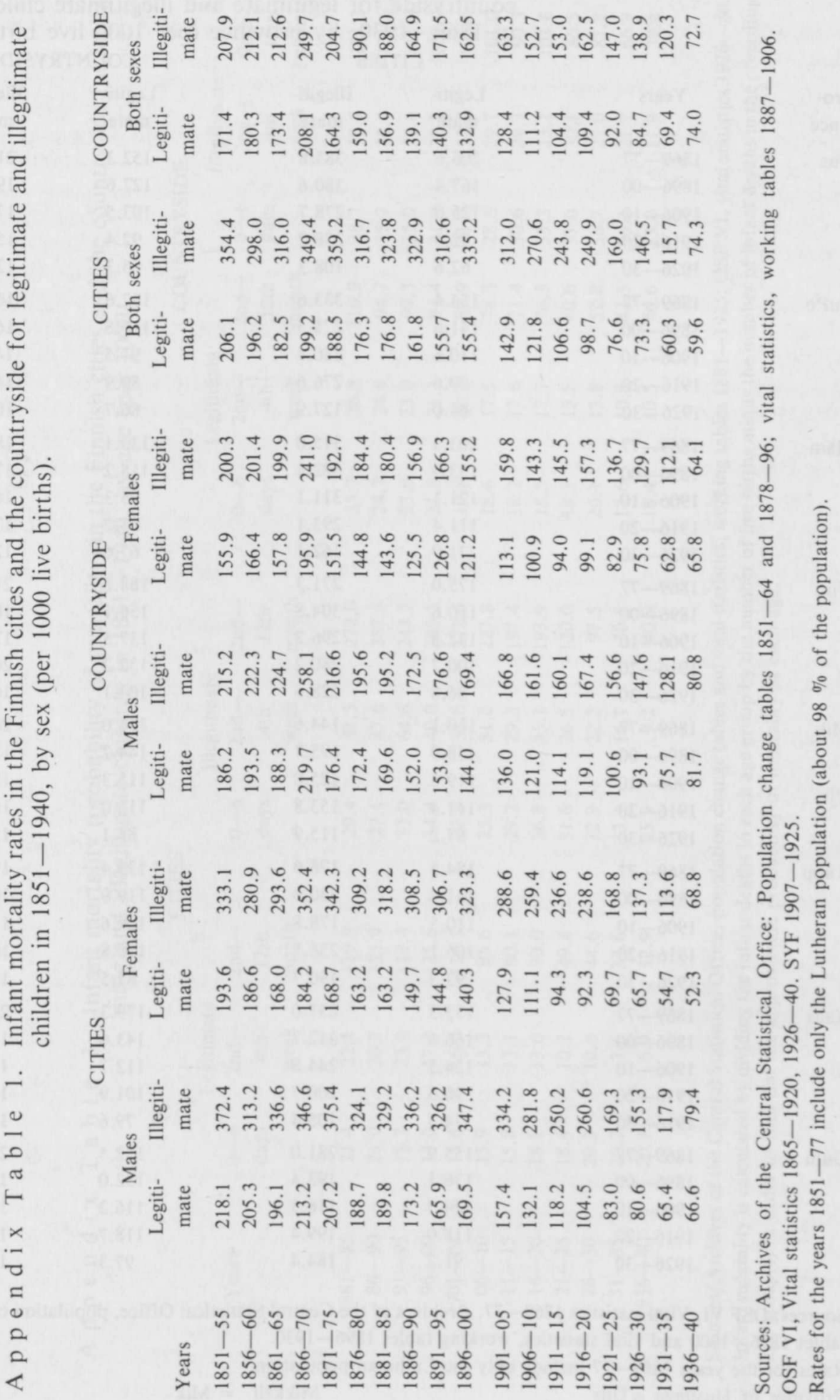


A p p e n d ix $\mathrm{Table}$ 2. Infant mortality rates in the Finnish cities and the countryside for legitimate and illegitimate children in 1869-1930, by province (per 1000 live births).

\section{CITIES}

\begin{tabular}{|c|c|c|c|c|c|}
\hline $\begin{array}{l}\text { Pro- } \\
\text { vince }\end{array}$ & Years & $\begin{array}{l}\text { Legiti- } \\
\text { mate }\end{array}$ & $\begin{array}{l}\text { Illegiti- } \\
\text { mate }\end{array}$ & $\begin{array}{l}\text { Legiti- } \\
\text { mate }\end{array}$ & $\begin{array}{l}\text { Illegiti- } \\
\text { mate }\end{array}$ \\
\hline \multirow[t]{5}{*}{ Uus } & $1869-77$ & 206.6 & 385.8 & 152.3 & 216.3 \\
\hline & $1896-00$ & 167.4 & 380.6 & 127.6 & 190.8 \\
\hline & $1906-10$ & 125.0 & 278.7 & 103.5 & 172.6 \\
\hline & $1916-20$ & 92.3 & 238.2 & 92.4 & 159.3 \\
\hline & $1926-30$ & 62.6 & 108.3 & 65.3 & 121.1 \\
\hline \multirow[t]{5}{*}{ TuPo } & $1869-77$ & 154.4 & 333.6 & 132.6 & 169.9 \\
\hline & $1896-00$ & 141.6 & 275.5 & 116.8 & 164.3 \\
\hline & $1906-10$ & 110.6 & 280.8 & 91.5 & 144.5 \\
\hline & $1916-20$ & 90.6 & 276.6 & 89.9 & 143.9 \\
\hline & $1926-30$ & 64.0 & 127.9 & 66.7 & 103.8 \\
\hline \multirow[t]{5}{*}{ Häm } & $1869-77$ & 203.3 & 315.0 & 133.1 & 189.1 \\
\hline & $1896-00$ & 153.9 & 382.8 & 118.2 & 171.1 \\
\hline & $1906-10$ & 121.1 & 311.1 & 93.3 & 169.7 \\
\hline & $1916-20$ & 111.4 & 293.1 & 95.2 & 174.1 \\
\hline & $1926-30$ & 71.9 & 162.1 & 67.6 & 122.0 \\
\hline \multirow[t]{5}{*}{ Viip } & $1869-77$ & 175.0 & 271.3 & 188.8 & 214.8 \\
\hline & $1896-00$ & 150.6 & 304.8 & 156.1 & 164.9 \\
\hline & $1906-10$ & 132.3 & 296.2 & 137.5 & 173.7 \\
\hline & $1916-20$ & 100.7 & 280.2 & 132.2 & 204.1 \\
\hline & $1926-30$ & 86.8 & 228.6 & 103.1 & 160.2 \\
\hline \multirow[t]{5}{*}{ Mik } & $1869-77$ & 160.1 & 144.6 & 154.0 & 200.4 \\
\hline & $1896-00$ & 158.0 & 195.7 & 144.2 & 153.9 \\
\hline & $1906-10$ & 119.5 & 125.0 & 115.3 & 157.4 \\
\hline & $1916-20$ & 111.4 & 153.8 & 113.0 & 167.8 \\
\hline & $1926-30$ & 87.2 & 115.9 & 88.1 & 159.8 \\
\hline \multirow[t]{5}{*}{ Kuop } & $1869-77$ & 184.5 & 178.6 & 139.4 & 191.9 \\
\hline & $1896-00$ & 131.4 & 230.0 & 119.9 & 101.4 \\
\hline & $1906-10$ & 110.5 & 178.8 & 104.6 & 113.1 \\
\hline & $1916-20$ & 106.1 & 236.5 & 110.8 & 162.9 \\
\hline & $1926-30$ & 93.3 & 190.7 & 87.5 & 150.7 \\
\hline \multirow[t]{5}{*}{ Vaas } & $1869-77$ & 153.3 & 231.0 & 179.3 & 202.3 \\
\hline & $1896-00$ & 166.6 & 312.7 & 143.6 & 176.2 \\
\hline & $1906-10$ & 124.3 & 244.8 & 112.7 & 136.7 \\
\hline & $1916-20$ & 96.6 & 200.7 & 101.9 & 140.4 \\
\hline & $1926-30$ & 74.3 & 105.4 & 79.6 & 133.3 \\
\hline \multirow[t]{5}{*}{ Oulu } & $1869-77$ & 155.9 & 281.0 & 152.5 & 202.6 \\
\hline & $1896-00$ & 136.1 & 193.4 & 132.0 & 161.6 \\
\hline & $1906-10$ & 124.5 & 116.3 & 116.2 & 153.0 \\
\hline & $1916-20$ & 118.0 & 199.4 & 118.7 & 158.0 \\
\hline & $1926-30$ & 91.2 & 184.4 & 97.3 & 180.3 \\
\hline
\end{tabular}

Sources: OSF VI, Vital statistics 1869-77. Archives of the Central Statistical Office, population change tables $1896-1900$ and vital statistics, working tables $1896-1930$.

Rates for the years $1869-77$ include only the Lutheran population.
Province of Uusimaa $=$ Uus
Mikkeli $=$ Mik
Turku and Pori $=$ TuPo (incl. also Ảland) Kuopio $=$ Kuop
Häme $=$ Häm
Vaasa $=$ Vaas
Viipuri $=$ Viip
Oulu $=$ Oulu 


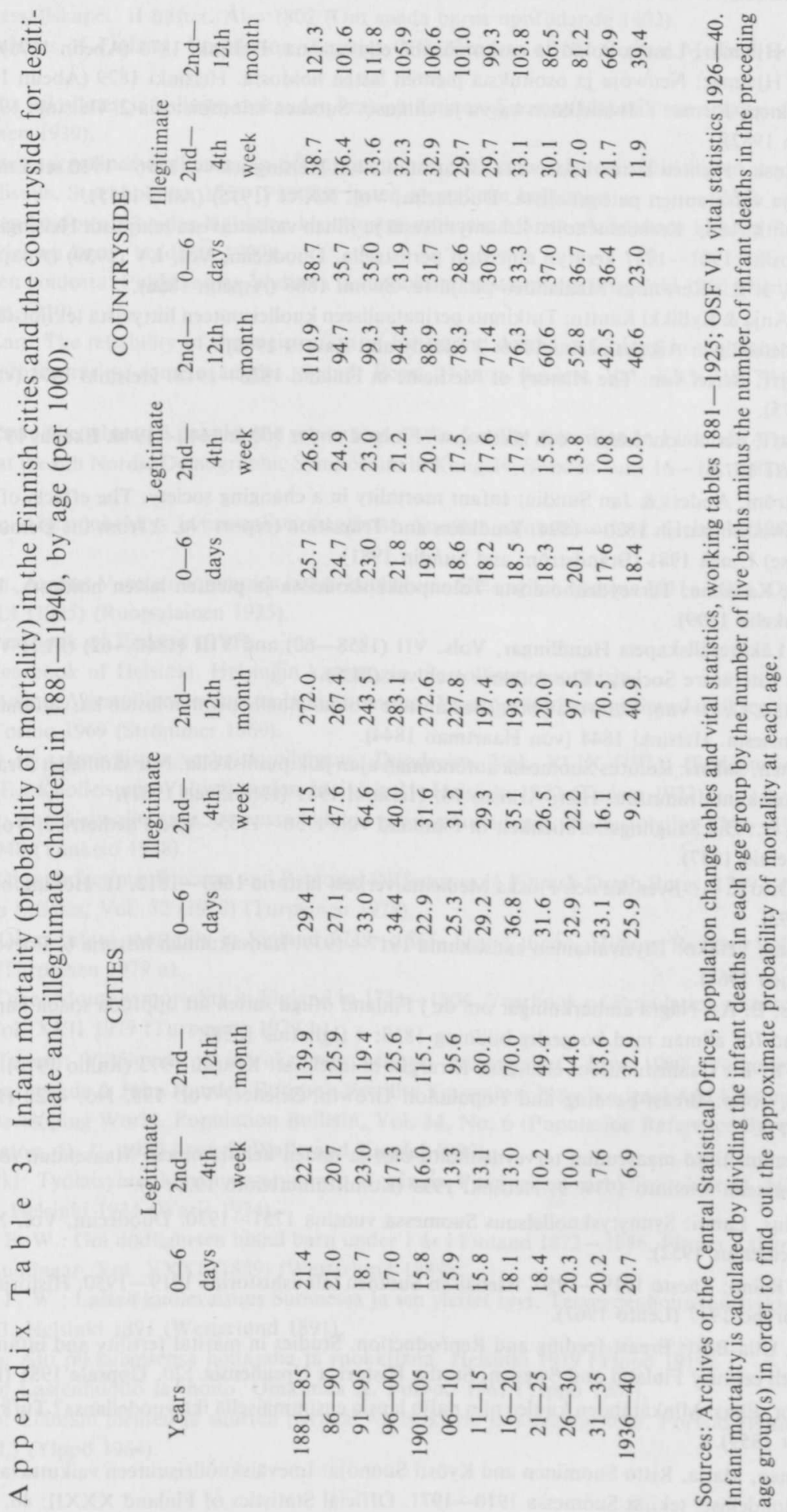




\section{References}

Abelin, Hjalmar: Lasten hoidosta ensimmäisinä elinvuosina. Helsinki 1875 (Abelin 1875).

Abelin, Hjalmar: Neuwoja ja osoituksia pienten lasten hoidosta. Helsinki 1879 (Abelin 1879).

Ahvenainen, Jorma: Taloudellinen kasvu ja elintaso. Suomen taloushistoria 2. Helsinki 1982 (Ahvenainen 1982).

Alho, Ensio: Pienten lasten kuolevaisuus vatsatauteihin Helsingissä vv. 1896-1910 sekä muutamia teorioja vatsatautien patogenesista. Duodecim, Vol. XXXI (1915) (Alho 1915).

Apajalahti, Aulis: Keskenmenojen lisääntymisestä ja siihen vaikuttavista tekijöistä Helsingin sairaaloista vuosilta 1901-1937 kerätyn aineiston perusteella. Duodecim, Vol, LV (1939) (Apajalahti 1939).

Aspelin, J. R.: Kertomus Maalahden pitäjästä. Suomi 1866 (Aspelin 1866).

Bardy, Anja \& Kyllikki Kauttu: Tutkimus perinataaliseen kuolleisuuteen liittyvistä tekijöistä. Sosiaalilääketieteellinen Aikakauslehti 1966: 3 (Bardy and Kauttu 1966).

Bonsdorff, Bertel von: The History of Medicine in Finland 1828-1918. Helsinki 1975 (von Bonsdorff 1975).

Bonsdorff, Bertel von: Läkare och läkekonst i Finland under 300 år 1640-1940. Ekenäs 1978 (von Bonsdorff 1978).

Brändström, Anders \& Jan Sundin: Infant mortality in a changing society. The effects of child care in a Swedish parish 1820-1894. Tradition and Transition (report No. 2 from the Demographic Data Base) Umeá 1981 (Brändström and Sundin 1981).

Eskelin, Karolina: Terveydenhoidosta Talonpoikaiskodeissa ja pienten lasten hoidosta. Helsinki 1899 (Eskelin 1899).

Finska Läkaresällskapets Handlingar, Vols. VII (1858-60) and VIII (1860-62) (FLH VII and VIII). Finnish Literature Society, The folklore archives (FLS).

Haartman, C. D. von: Neuwoja yhteiselle kansalle Pohjanmaalla pienten lasten kasvattamisesta ja ruokkimisesta. Helsinki 1844 (von Haartman 1844).

Heikkinen, Sakari: Kulutus Suomessa autonomian ajan jälkipuoliskolla. När samhället förändras - Kun yhteiskunta muuttuu. Hist. Arkisto 76. Helsinki 1981 (Heikkinen 1981).

Heiniö, P.: Die Säuglingssterblichkeit in Finnland von 1750-1935. Acta Paediatrica, Vol. XXI (1937) (Heiniö 1937).

Hjelt, Otto E. A.: Svenska och Finska Medicinalverkets historia 1663-1812. II. Helsingfors 1892 (Hjelt 1892).

Huttunen, Veikko: Täysivaltainen kansakunta 1917-1939. Kansakunnan historia 6. Porvoo 1968 (Huttunen 1968).

lgnatius, E. A.: Några anmärkningar om de i Finland öfliga sätten att uppföda späda barn. Litteraturblad för allmän med borgerlig bildning 1858: 4 (Ignatius 1858).

Kallio, K. E.: Osallistumiseni elämään. Kirurgin muistelmat. Keuruu 1973 (Kallio 1973).

Knodel, John: Breast-Feeding and Population Growth. Science, Vol. 198, No. 4322 (1977) (Knodel 1977).

Komiteanmietintö maaseudun terveydenhoito-olot ja niiden kehittäminen. Maaseudun terveydenhoitokomitean mietintö 1939: 9. Helsinki 1939 (Komiteanmietintö 1939: 9).

Leidenius, Laimi: Synnytyskuolleisuus Suomessa vuosina 1751-1930. Duodecim, Vol. XLVIII (1932) (Leidenius 1932).

Lento, Reino: Väestö 1919-1950. Itsenäisen Suomen taloushistoriaa 1919-1950. Historian aitta XVII. Porvoo 1917 (Lento 1967).

Lithell, Ulla-Britt: Breast-feeding and Reproduction. Studies in marital fertility and infant mortality in 19th century Finland and Sweden. Studia Historica Upsaliensia 120. Uppsala 1981 (Lithell 1981).

Lönnrot, Elias: Minkätähden kuolee niin paljo lapsia ensimmäisellä ikäwuodellansa? Turku 1859 (Lönnrot 1859$)$.

Mustonen, Maija, Risto Suominen and Kyösti Suonoja: Imeväiskuolleisuuteen vaikuttavat sosiaaliset ja taloudelliset tekijät Suomessa 1910-1971. Official Statistics of Finland XXXII: 46. Helsinki 1976 (Mustonen et al. 1976). 
Om späda barns upfödande. Hushålls-underrättelser för menige man. Published by Kongl. Finska Hushållningssällskapet. II häftet. Ảbo 1802 (Om späda barns uppfödande 1802).

Official Statistics of Finland. Population statistics (VI); Reports of the Central Medical Board (XI) (OSF).

Pelkonen, E.: Rikollinen ja laillinen raskauden keskeyttäminen. Suomen lääkäriliiton aikakauslehti 1939 (Pelkonen 1939).

Pienden lasten tarpellinen holhomus ja perääncatzomus, nijn cuin caickein christillisten wanhembain welwollisuus. Stockholmisa 1756 (Pienden lasten tarpellinen holhomus $-\ldots-1756$ ).

Pienten lasten hoidosta. Useiden lääkärien kirjoitusten mukaan. Martta-yhdistyksen kirjasia 7. Helsinki 1900 (Pienten lasten hoidosta 1900).

Pienten lasten hoidosta. Published by Yhdistys lastenhoidon edistämiseksi. Helsinki 1910 (Pienten lasten hoidosta 1910).

Pitkänen, Kari: The reliability of the registration of births and deaths in Finland in the eighteenth and nineteenth centuries: some examples. Scand. Econ. History Review, Vol. XXV (1977) (Pitkänen 1977).

Pitkänen, Kari: The educated people: the precursors of the fertility transition in Finland. A paper presented at the 6th Nordic Demographic Symposium in Kungälv, Sweden June 16-19, 1982 (Pitkänen 1982).

Rasila, Viljo: Väestönkehitys ja sosiaaliset ongelmat. Suomen taloushistoria 2. Helsinki 1982 (Rasila 1982).

Ruotsalainen, Armas: Vuotta nuorempien lasten kuolleisuus Helsingissä vuosina 1911-1924. Duodecim, Vol. XLI (1925) (Ruotsalainen 1925).

Statistical Yearbook of Finland (SYF).

Statistical Yearbook of Helsinki. Helsingin kaupungin tilastollinen vuosikirja.

Strömmer, Aarno: Väestöllinen muuntuminen Suomessa. Väestöpoliittisen tutkimuslaitoksen julkaisuja A:13. Tornio 1969 (Strömmer 1969).

Söderström, Hj.: Imeväisten varhaiskuolleisuus. Duodecim, Vol. XLIX (1933) (Söderström 1933).

Tudeer, A. E.: Kuolleisuus. Valtiotieteiden käsikirja II. Helsinki 1922 (Tudeer 1922).

Tunkelo, A.: Imeväiskuolleisuus Suomessa kahden vuosisadan aikana. Taulustolaitos 1748-1948. Helsinki 1948 (Tunkelo 1948).

Turpeinen, Oiva: Infectious Diseases and Regional Differences in Finnish Death Rates, 1749-1773. Population Studies, Vol. 32 (1978) (Turpeinen 1978).

Turpeinen, Oiva: Infant mortality in Finland 1749-1865. Scand. Econ. History Review, Vol. XXVII (1979) (Turpeinen 1979 a).

Turpeinen, Oiva: Monthly mortality in Finland in 1751-1806. Yearbook of Population research in Finland, Vol. XVII 1979 (Turpeinen 1979 b).

Valkonen, Tapani: Väkiluvun ja ikärakenteen kehitys. Suomalaiset. Juva 1980 (Valkonen 1980).

Walle, Etienne van de \& John Knodel: Europe's Fertility Transition: New Evidence and Lessons for Today's Developing World. Population Bulletin, Vol. 34, No. 6 (Population Reference Bureau, Inc., Washington, D. C. 1980 (van de Walle and Knodel 1980).

Waris, Heikki: Työläisyhteiskunnan syntyminen Helsingin Pitkänsillan pohjoispuolelle II. Hist. tutk. XVI, 2. Helsinki 1934 (Waris 1934).

Westerlund, F. W.: Om dödligheten bland barn under 1 ảr i Finland 1872-1886. Finska Läkaresällskapets Handlingar, Vol. XXXI (1889) (Westerlund 1889).

Westerlund, F. W.: Lasten kuolevaisuus Suomessa ja sen yleiset syyt. Terveydenhoitoyhdistyksen lentokirjoja 3. Helsinki 1891 (Westerlund 1891).

Ylppö, Arvo: Äiti pikkulapsensa hoitajana ja ruokkijana. Helsinki 1919 (Ylppö 1919).

Ylppö, Arvo: Lastenhuolto ja -hoito. Oma maa X. Porvoo 1961 (Ylppö 1961).

Ylppö, Arvo: Elämäni pienten ja suurten parissa. Muistikuvia ja kuvamuistoja. Porvoo-Helsinki 1964 (2nd. ed.) (Ylppö 1964). 


\section{Newspapers}

Aamulehti 1886

Helsingfors Tidningar 1863

Hämäläinen 1861

Pohjalainen 1890

Tidningar utg. af et sällskap i Åbo 1783 and 1785

Toveritar 1925-26 